\title{
Cryosphere Microbiome Biobanks for Mountain Glaciers
} in China

\author{
Anzhou Ma ${ }^{1,2, *,+(\mathbb{D}}$, Jiejie Zhang ${ }^{1,3,4,+} \mathbb{D}$, Guohua Liu ${ }^{1,2}$, Xuliang Zhuang ${ }^{1,5} \mathbb{D}$ and Guoqiang Zhuang ${ }^{1,2, *}$ \\ 1 Research Center for Eco-Environmental Sciences, Chinese Academy of Sciences, Beijing 100085, China; \\ zhangjiejie19@mails.ucas.ac.cn (J.Z.); ghliu@rcees.ac.cn (G.L.); xlzhuang@rcees.ac.cn (X.Z.) \\ 2 College of Resources and Environment, University of Chinese Academy of Sciences, Beijing 100049, China \\ 3 Sino-Danish College, University of Chinese Academy of Sciences, Beijing 101400, China \\ 4 Sino-Danish Center for Education and Research, Beijing 101400, China \\ 5 Institute of Tibetan Plateau Research, Chinese Academy of Sciences, Beijing 100101, China \\ * Correspondence: azma@rcees.ac.cn (A.M.); gqzhuang@rcees.ac.cn (G.Z.) \\ + These authors contributed equally to this work.
}

Citation: Ma, A.; Zhang, J.; Liu, G.; Zhuang, X.; Zhuang, G. Cryosphere Microbiome Biobanks for Mountain Glaciers in China. Sustainability 2022, 14, 2903. https://doi.org/10.3390/ su14052903

Academic Editor: Franco Salerno

Received: 29 January 2022

Accepted: 27 February 2022

Published: 2 March 2022

Publisher's Note: MDPI stays neutral with regard to jurisdictional claims in published maps and institutional affiliations.

Copyright: (c) 2022 by the authors. Licensee MDPI, Basel, Switzerland. This article is an open access article distributed under the terms and conditions of the Creative Commons Attribution (CC BY) license (https:// creativecommons.org/licenses/by/ $4.0 /)$.

\begin{abstract}
The glaciers in China have an important role as one of the most climate-sensitive constituents of the Tibetan Plateau which is known as the Asian Water Tower. Although the cryosphere is one of the most extreme environments for organisms, the soils of the glacier foreland harbor surprisingly rich microbiomes. A large amount of accelerated glacier retreat accompanied by global warming will not only raise the sea level, but it will also lead to the massive release of a considerable amount of carbon stored in these glaciers. The responses of glacier microbiomes could alter the biogeochemical cycle of carbon and have a complex impact on climate change. Thus, understanding present-day and future glacier microbiome changes is crucial to assess the feedback on climate change and the impacts on ecosystems. To this end, we discuss here the diversity and biogeochemical functions of the microbiomes in Chinese mountain glacier ecosystems.
\end{abstract}

Keywords: glaciers; climate warming; microbiome; microbial diversity; carbon cycle

\section{Introduction}

Glaciers are a major component of the cryosphere, which is one of the five major spheres of the climate system [1]. Glaciers can be divided into ice caps and mountain glaciers based on their sizes and geographical characteristics [2]. Although the glacier environment is cold, nutrient-poor, and receives a large amount of UV radiation, it still harbors diverse and active microorganisms [3-5]. The microorganisms in this important ecosystem are involved in the biogeochemical cycles of various elements, including carbon, nitrogen, and sulfur [6-8]. The community structure and functions of these microorganisms are affected by the physicochemical properties of the glaciers, which are closely related to climate and environmental changes [9-13].

Current global warming is an undoubtedly trend characterized by increasingly serious temperature increase. According to the Sixth Assessment Report of the Intergovernmental Panel on Climate Change (IPCC), the global surface temperature in 2011-2020 increased by $1.09^{\circ} \mathrm{C}$ compared to $1850-1900[14,15]$. Under the impact of human activities and the self-reinforcing feedbacks of the Earth, this temperature increase will continue [16]. The cryosphere, which includes ice sheets, glaciers, and permafrost, is the most sensitive to these temperature changes and will be the most strongly affected. Arctic summer sea ice, the Greenland Ice Sheet, Alpine glaciers, and the west Antarctic Ice Sheet will face the threat of disappearance when the global surface temperature increases by $1-3{ }^{\circ} \mathrm{C}$ [17]. Several studies have concluded that mountain glaciers will be more easily affected by climate change, and their retreat rate is higher than those of the Arctic and Antarctic Ice Sheets $[17,18]$. Based on the observed global mean sea level change in 1901-2018, the retreat of mountain glaciers contributed $67.2 \mathrm{~mm}$ to the sea level rise $[15,19]$. 
China has the largest and most numerous glaciers in the middle- and low-latitude regions of the world $[20,21]$. These mountain glaciers tend to melt because their temperatures are usually equal to or exceed the melting point of ice. When glacier ice melts, newly exposed habitats are formed, with diverse microbial communities. These diverse microbial communities conduct important biogeochemical processes (e.g., the microbially mediated carbon cycle), which are important aspects of glacier ecology [22,23]. Although it is difficult to culture the special glacier microorganisms using traditional cultivation methodologies, a novel technique based on uncultured methods (e.g., next-generation sequencing) provides opportunities for improving geomicrobiological studies of mountain glaciers [23,24].

Here, we review the existing knowledge of microbial diversity and functions, as well as the biogeochemical interactions, in Chinese mountain glacier ecosystems. Cyanobacteria and algae, the important components of the cryosphere microbiome, are not discussed in detail due to the few related reports in Chinese glaciers. Global warming is closely related with carbon cycle, which would be greatly affected by the microorganisms. We also discuss the interactions between the microbial community of mountain glaciers and the changing climate from the involvement of microbes in carbon biogeochemical cycle, highlighting the importance of understanding the ecological implications of climate change and glacier melting.

\section{Status of Glacier Distribution in China}

According to the Second Chinese Glacier Inventory (SCGI), 48,571 glaciers were identified in Tibetan, Qinghai, Gansu, Sichuan, and Yunnan provinces, with a total area of $51,766.08 \mathrm{~km}^{2}$ and an ice volume of $4494.00 \pm 175.93 \mathrm{~km}^{3}$ [2]. They are mainly small glaciers with areas of less than $1.0 \mathrm{~km}^{2}$, accounting for $80 \%$ of all glaciers in China [2]. Based on the development and geomorphological conditions as well as movement properties, Chinese glaciers are classified as mountain glaciers, located in the western mountains, including the Hengduan Mountains, Himalayan Mountains, Nyainqentanglha Mountains, Karakoram Mountains, Kunlun Mountains, Qilian Mountains, Tianshan Mountains, and Altay Mountains from south to north (Figure 1).

According to the development and physical properties of glaciers, Chinese glaciers can be divided into continental glaciers, sub-continental glaciers, and temperate glaciers [25-28]. Covering an area of more than $13,200 \mathrm{~km}^{2}$, with abundant summer monsoon precipitation and an annual retreat rate of 4-66 m/year [29,30], the temperate glaciers are distributed in the eastern Himalayan Mountains, the central-eastern Nyainqentanglha Mountains, and the Hengduan Mountains [28]. This type of glacier is more sensitive to air temperature than precipitation changes, and the equilibrium altitude line would rise by $153 \mathrm{~m}$ if the temperature increased by $1{ }^{\circ} \mathrm{C}$ [31]. Sub-continental glaciers account for $46 \%$ (about 27,200 $\mathrm{km}^{2}$ ) of the all glaciers in China and are mainly distributed in the Qilian Mountains, the eastern Kunlun Mountains, the eastern Tanggula Mountains, the western Nyainqentanglha Mountains, part of the Gangdise Mountains, the north slopes of the central-western Himalayas, and the north slopes of the Karakoram Mountains [28]. With an annual precipitation of 500-1000 m, they have lower retreat rates; for example, Tianshan Glacier No. 1 has retreated by about $5 \mathrm{~m}$ every year [32]. In comparison, continental glaciers account for one-third of the total glacier area, covering $19,000 \mathrm{~km}^{2}$, and are characterized by the lowest annual average temperature (below $0^{\circ} \mathrm{C}$ ). Their dry climate, with an annual precipitation of 200-500 mm, causes the ice to flow slowly. Such glaciers are located in the western Qilian Mountains, western Gangdise Mountains, western Tanggula Mountains, eastern Pamir Plateau, the central and western Kunlun Mountains, and the Qiangtang Plateau [28,31]. 


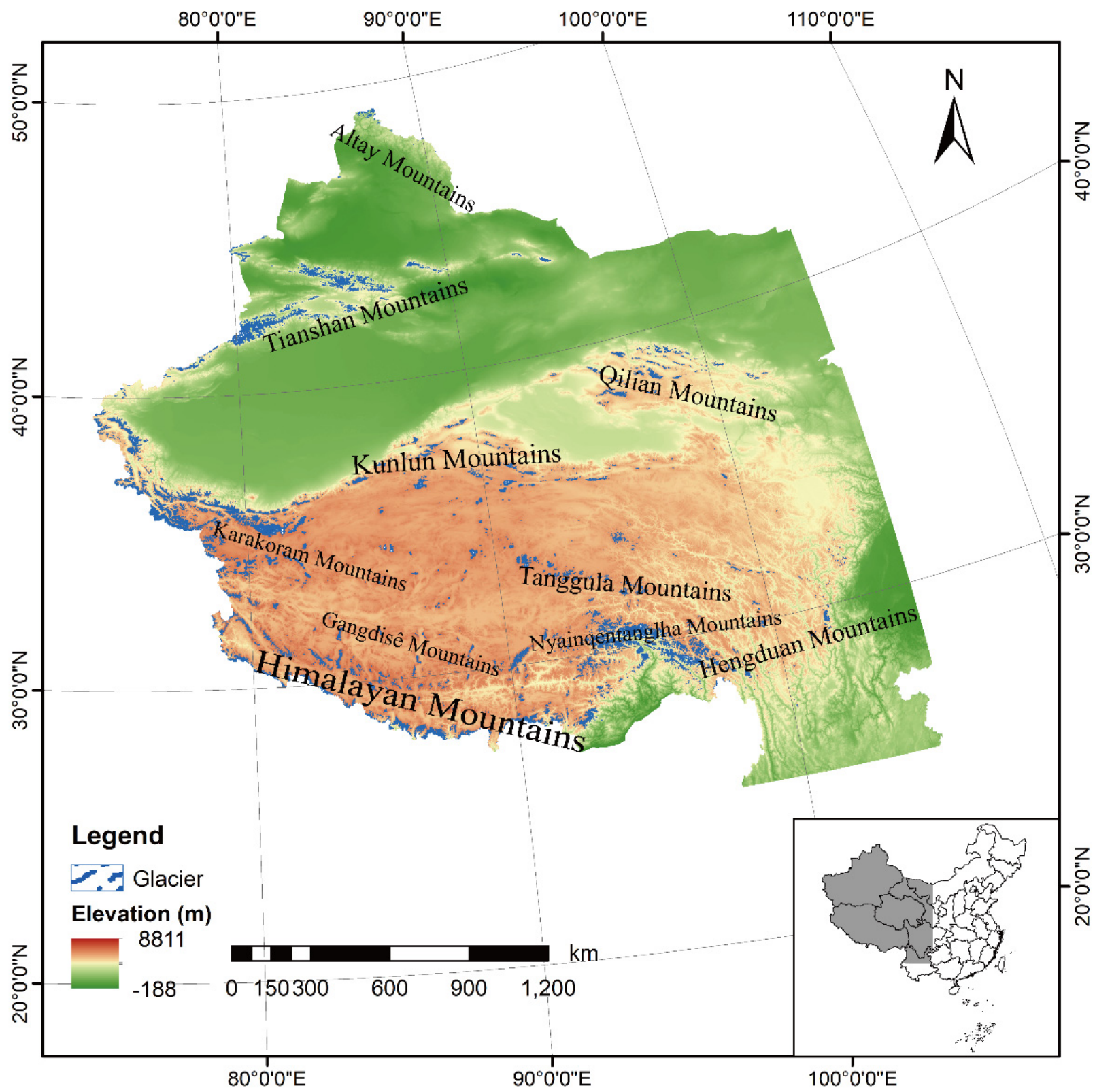

Figure 1. The distribution map of glaciers in western China based on the Second Chinese Glacier Inventory.

As a result of continued global warming, glaciers are generally exhibiting a retreating trend. Nearly all of the Chinese glaciers have retreated significantly and at an accelerated rate (Table 1). From 1960 to the beginning of the 21st century, the annual average rate of change of the glacier area in China was $0.3 \%$, and their total area shrank by $10.1 \%$ [33]. The area of glaciers decreased by $1393.97 \mathrm{~km}^{2}$ in only 10 years (2008-2018), which accounted for $3.74 \%$ of the total area of glaciers in China [34]. Based on remote sensing monitoring, $82.2 \%$ of these glaciers were found to be shrinking. The retreat size and proportion varied for each glacier, with significant regional differences [35]. In particular, the smaller glaciers were found to be more sensitive to global warming [36-38]. 
Table 1. Retreating rates of glacier areas from western China.

\begin{tabular}{|c|c|c|c|c|c|}
\hline \multirow{2}{*}{ Location } & \multirow{2}{*}{ Period } & \multicolumn{2}{|c|}{ Area $\left(\mathrm{km}^{2}\right)$} & \multirow{2}{*}{ Retreat Area (\%) ${ }^{1}$} & \multirow{2}{*}{$\begin{array}{l}\text { Retreat Rate } \\
\left(\mathrm{km}^{2} / \text { Year) }\right.\end{array}$} \\
\hline & & Beginning & End & & \\
\hline Altai Mountains (Friendship Peak) [39] & 1959-2008 & 214.04 & 148.94 & 30.41 & 1.33 \\
\hline Altai Mountains (north slope of Sawuer Mountain [40] & 1959-2013 & 15.09 & 9.42 & 37.57 & 0.11 \\
\hline Altun Mountains [41] & 1970-2016 & 326.02 & 272.95 & 16.28 & 1.15 \\
\hline $\begin{array}{l}\text { Eastern of Gangdisê, Nyainqentanglha Mountains, eastern } \\
\text { of Himalayas Mountains (Parlung Zangbo River) [42] }\end{array}$ & 1994-2015 & 776.44 & 324.72 & 58.18 & 21.51 \\
\hline Gangdisê Mountains [43] & 1970-2016 & 2160.50 & 1306.45 & 39.53 & 18.57 \\
\hline $\begin{array}{l}\text { North slope of the Karakoram Mountains } \\
\text { (Yarkant River basin) [36] }\end{array}$ & 1968-2009 & 6341.82 & 5414.77 & 14.62 & 22.61 \\
\hline Western Karakoram Mountains (Gilgit River Basin) [44] & 1993-2016 & 1126.77 & 1080.95 & 4.07 & 1.99 \\
\hline Eastern Pamir [45] & 1960-2009 & 2275.8 & 2054.0 & 9.75 & 4.53 \\
\hline Qiangtang Plateau (Zangser Kangri Glacier) [46] & 1971-2015 & 316.97 & 297.65 & 6.10 & 0.44 \\
\hline Qilian Mountains [47] & 1956-2010 & 2000.62 & 1597.81 & 20.13 & 7.46 \\
\hline Qilian Mountains [48] & 1987-2018 & 2080.39 & 1442.09 & 30.68 & 20.59 \\
\hline Middle Qilian Mountain [49] & $1956-2003$ & 397.41 & 311.02 & 21.74 & 1.84 \\
\hline Western Qilian Mountain [50] & 1957/1966-2010 & 332.48 & 275.27 & 17.21 & 1.17 \\
\hline Qilian Mountain (Heihe River Basin) [51] & 1990-2010 & 66.30 & 13.37 & 79.83 & 2.65 \\
\hline Central Qilian Mountain (Hulugou Basin) [52] & 1956-2011 & 2.11 & 1.45 & 31.28 & 0.01 \\
\hline Qilian Mountain (Laohugou Glacier No. 12) [53] & 1957-2015 & 21.91 & 20.37 & 7.03 & 0.03 \\
\hline Que' er Mountains (Southeastern Tibetan Plateau) [54] & 1987-2016 & 103.63 & 52.82 & 49.03 & 1.75 \\
\hline Sawuer Mountain [55] & 1977-2017 & 23.00 & 12.49 & 45.70 & 0.26 \\
\hline Tianshan Mountains [56] & 1960-2010 & 8799.82 & 7179.77 & 18.41 & 32.40 \\
\hline Northern slope of Tianshan Mountains (Urumqi Basin) [57] & 1964-2014 & 57.40 & 20.18 & 64.84 & 0.74 \\
\hline Eastern Tian Shan (Southern slope of Kalik Mountain) [58] & 1972-2005 & 66.3 & 58.1 & 12.37 & 0.25 \\
\hline Tianshan Mountains (South slope of Sawuer Mountain [40] & 1959-2013 & 2.60 & 0.71 & 72.69 & 0.04 \\
\hline Eastern Tianshan Mountains (Bogda regions) [59] & 1990-2015 & 158.17 & 104.44 & 33.97 & 2.15 \\
\hline Eastern Tianshan Mountains (Karlik regions) [59] & 1990-2015 & 158.88 & 107.80 & 32.15 & 2.04 \\
\hline Tianshan Mountains (Tomur National Nature Reserve) [60] & 1992-2017 & 1600.56 & 1534.46 & 4.13 & 2.64 \\
\hline Tianshan Mountains (Urumqi Glacier No. 1) [61] & 2012-2018 & 1.59 & 1.52 & 4.40 & 0.01 \\
\hline Himalayas Mountains [62] & 1990-2015 & $23,229.27$ & $20,676.17$ & 10.99 & 102.12 \\
\hline $\begin{array}{l}\text { Eastern Himalayas Mountains } \\
\text { (Namjagbarwa Mountain) [63] }\end{array}$ & 1980-2015 & 294.72 & 219.48 & 25.53 & 2.15 \\
\hline $\begin{array}{l}\text { Eastern Himalayas Mountains } \\
\text { (China and Bhutan border area) [64] }\end{array}$ & 1990-2015 & 1779.37 & 1587.50 & 10.78 & 7.67 \\
\hline Western Himalayas Mountains (Chenab Basin) [65] & 1993-2016 & 2847.91 & 2683.35 & 5.78 & 7.15 \\
\hline $\begin{array}{l}\text { Northern Himalayas Mountains } \\
\text { (Chema Yongdrung Glacier) [66] }\end{array}$ & 1976-2019 & 22.98 & 21.37 & 7.01 & 0.04 \\
\hline Tanggula Mountains (Geladandong region) [67] & 1986-2015 & 997.47 & 905.41 & 9.23 & 3.17 \\
\hline
\end{tabular}

${ }^{1}$ Retreat area was the ratio of glacier area change in the time series to the glacier area of the beginning of the time series. ${ }^{2}$ Retreat rate was the annual reduction of glacier area, calculated based on the change of glacier area and the corresponding time series. 


\section{Diversity and Community Structure of Glacial Microbiomes in China}

Despite the harsh environment with low temperatures and limited nutrients, microorganisms play important roles in the glacier forelands and have a high level of diversity, including abundant bacteria, archaea, fungi, and viruses [68]. In the early stage, microbial research mainly depended on traditional microbial isolation and culture methods, which hindered our acknowledgement of cryospheric microbes. Since the 1990s, the emergence of non-culturally microbial research methods, including cloning libraries and high-throughput sequencing, has made the study of cryospheric microbiomes more comprehensive and accurate as well as accelerating the cryospheric microbial research [69]. The glaciers in the Tibetan Plateau cover an area of $47,000 \mathrm{~km}^{2}$, accounting for $80 \%$ of the total glacier area in China [70], making this main region suitable for glacial microbial research in China. The Pamir Plateau and the Tianshan Mountains are other active regions for glacial microbial research (Table 2). 
Table 2. Summary of the microbial diversity data for glaciers in China.

\begin{tabular}{|c|c|c|c|c|}
\hline Location & Sample Type & $\begin{array}{l}\text { Microbial Abundance } \\
\quad(\text { Cells } / \mathrm{mL})\end{array}$ & $\begin{array}{l}\text { Culturable Bacteria } \\
\text { Abundance (CFU/mL) }\end{array}$ & Dominant Microbial Groups \\
\hline Dunde ice cap, Qilian Mountain region [71] & Ice core & $1.3 \times 10^{5}-1.9 \times 10^{6}$ & & $\begin{array}{c}\text { Blastococcus sp./Propionibacterium, Cryobacterium-related, Flavobacterium sp., } \\
\text { Pedobacter sp., Polaromonas sp. }\end{array}$ \\
\hline Guliya ice cap, Tibetan Plateau [72] & Ice core & 180 & & $\begin{array}{l}\text { Arthrobacter, Aureobacterium, Bacillus, Bradyrhizobium, Brevibacterium, Cellulomonas, } \\
\text { Clavibacter, Flavobacterium, Frankia, Friedmanniella, Methylobacterium, Microbacterium, } \\
\text { Micrococcus, Micromonospora, Mycobacte-rium, Nocardia, Nocardioides, Paenibacillus, } \\
\text { Planococcus, Propioniferax, Sphingomonas, Staphylococcus, and Stenotro-phomonas }\end{array}$ \\
\hline Malan Glacier, Tibetan Plateau [73] & Ice core & $50-410$ & $0-85$ & $\begin{array}{c}\text { Micrococcus, Staphylococcus, Bacillus, Brevibacter, Achromobacter, Pseudomonas, } \\
\text { Alcaligenes, Flavobacterium, Arthrobacter, Nocardia, Streptomyces }\end{array}$ \\
\hline Malan Glacier, Tibetan Plateau [74] & Ice core & & & Alphaproteobacteria, Betaproteobacteria, Gammaproteobacteria, $\mathrm{CFB}^{1}$ \\
\hline Muztagata ice core, Pamir Plateau [75] & Ice core & & $0-127$ & Alphaproteobacteria, Gammaproteobacteria, Cryobacteria, CFB, HGC ${ }^{2}$ \\
\hline $\begin{array}{l}\text { Muztagata Glacier, western margin of the Tibetan } \\
\text { Plateau [71] }\end{array}$ & Ice core & $4.4 \times 10^{4}-8.7 \times 10^{5}$ & & $\begin{array}{c}\text { Polaromonas sp., Enterobacte sp., Acinetobacter sp., Flexibacter sp., Flacvisolibacter sp., } \\
\text { Thermus sp., Propionibacterium/Luteococcus sp. }\end{array}$ \\
\hline Urumqi Glacier No. 1, Tianshan Mountains [76] & Ice core & $1.4 \times 10^{3}-1.0 \times 10^{5}$ & $0-300$ & $\begin{array}{c}\text { Alphaproteobacteria, Betaproteobacteria, Gammaproteobacteria, Bacilli, } \\
\text { Actinobacteria, Sphingobacteria, Flavobacteria }\end{array}$ \\
\hline Urumqi Glacier No. 1, Tianshan Mountains [77] & Cryoconite & & & Oscillatoriales, Chroococcales \\
\hline Yushugou Glacier, eastern Tianshan Mountains [78] & Cryoconite granules & & & Oscillatoriales, Chroococcales \\
\hline East Rongbuk Glacier, Mount Everest [79] & Meltwater & & & $\begin{array}{l}\text { Alphaproteobacteria, Betaproteobacteria, Gammaproteobacteria, } \\
\text { Actinobacteria, Firmicutes }\end{array}$ \\
\hline Laohugou Glacier No. 12, Qilian Mountains [80] & Meltwater, surface ice & & & $\begin{array}{c}\text { Proteobacteria, Firmicutes, Bacteroidetes, Actinobacteria, Verrucomicrobia, } \\
\text { Acidobacteria, Planctomycetes, Cyanobacteria/Chloroplast }\end{array}$ \\
\hline Yangbark Glacier, Muztagata [81] & Meltwater, surface ice, snow & & & $\begin{array}{c}\text { Alphaproteobacteria, Betaproteobacteria, Gammaproteobacteria, Firmicutes, } \\
\text { Actinobacteria, Bacteroidetes }\end{array}$ \\
\hline Qiyi Glacier, Qilian Mountains [82] & Surface ice/snow & & & Oscillatoriales, Chroococcales \\
\hline Qiyi Glacier, Qilian Mountains [83] & Snow pit, runoff & $\begin{array}{c}9.1 \times 10^{3} \text { (snow) } \\
42.0 \times 10^{3} \text { (runoff) }\end{array}$ & $\begin{array}{l}126.9 \text { (snow) } \\
271.8 \text { (runoff) }\end{array}$ & $\begin{array}{c}\text { Alphaproteobacteria, Betaproteobacteria, Gammaproteobacteria, Actinobacteria, } \\
\text { Bacteroidetes, Firmicutes, }\end{array}$ \\
\hline Yala Glacier, southern slope of the Himalayas [84] & Surface snow & $1.1 \times 10^{4}-9.0 \times 10^{4}$ & & $\begin{array}{c}\text { Alphaproteobacteria, Betaproteobacteria, Cyanobacteria, Actinobacteria, } \\
\text { Bacteroidetes, Firmicutes }\end{array}$ \\
\hline
\end{tabular}


Table 2. Cont.

\begin{tabular}{|c|c|c|c|c|}
\hline Location & Sample Type & $\begin{array}{l}\text { Microbial Abundance } \\
\quad(\text { Cells } / \mathrm{mL})\end{array}$ & $\begin{array}{l}\text { Culturable Bacteria } \\
\text { Abundance (CFU/mL) }\end{array}$ & Dominant Microbial Groups \\
\hline Meikuang Glacier, Tibetan Plateau [85] & Surface snow, snow pit & & 58.07 & $\begin{array}{c}\text { Bacteroidetes, Actinobacteria, Firmicutes, Alphaproteobacteria, } \\
\text { Betaproteobacteria, Gammaproteobacteria }\end{array}$ \\
\hline Xiao-Dongkemadi Glacier, Tibetan Plateau [85] & Surface snow, snow pit & & 18.54 & $\begin{array}{l}\text { Actinobacteria, Firmicutes, Alphaproteobacteria, } \\
\text { Betaproteobacteria, Gammaproteobacteria }\end{array}$ \\
\hline Yuzhufeng Glacier, Tibetan Plateau [85] & Surface snow, snow pit, & & 35.53 & Firmicutes, Actinobacteria, Alphaproteobacteria, Betaproteobacteria \\
\hline DongRongbu Glacier, Qomolangma region [86] & Snow pit & $5.7 \times 10^{3}-2.3 \times 10^{4}$ & & $\begin{array}{l}\text { Alphaproteobacteria, Betaproteobacteria, Gammaproteobacteria, Actinobacteria, } \\
\text { Firmicutes, CFB, Cyanobacteria, Eukaryotic chloroplast, TM7 candidate phylum }\end{array}$ \\
\hline Glaciers, Yulong Mountain regions [87] & Snow pit & $1.4 \times 10^{3}-3.9 \times 10^{3}$ & $8-96$ & Alphaproteobacteria, Actinobacteria, Firmicutes \\
\hline Miaoergou glacier, East Tianshan Mountains [88] & Sonw pit & $1.03 \times 10^{4}-1.74 \times 10^{4}$ & $1.18 \times 10^{2}-4.96 \times 10^{2}$ & Alphaproteobacteria, Betaproteobacteria, Gammaproteobacteria, CFB, HGC, LGC ${ }^{3}$ \\
\hline ZhuoAoyou Peak, Tibetan Plateau [89] & Sonw pit & & & Caulobacter, Ralstonia, Cupriavidus, Pelomonas, Pseudomonas \\
\hline Chongce Ice Cap, West Kunlun Mountains [90] & Glacial snow, exposed soil & & & $\begin{array}{c}\text { Actinobacteria, Proteobacteria, Deinococcus-Thermus, Acidobacteria, } \\
\text { Armatimonadetes, Bacteroidetes, Chloroflexi, Cyanobacteria, Candidate division } \\
\text { FBP, Gemmatimonadetes, Planctomycetes, Verrucomicrobia }\end{array}$ \\
\hline $\begin{array}{l}\text { Hailuogou glacier retreat area, } \\
\quad \text { Gongga Mountain [91] }\end{array}$ & Exposed soil & & & Proteobacteria, Acidobacteria, Bacteroidetes, Acttinobacteria \\
\hline Laohugou Glacier No. 12, Qilian Mountains [92] & Exposed soil & & & Proteobacteria, Cyanobacteria, Actinobacteria. \\
\hline Mingyong Glacier, Yunnan Province [93] & Exposed soil & & & $\begin{array}{c}\text { Pseudomonas, Yersinia, Stenotrophomonas, Bacillus, Brevibacterium, } \\
\text { Streptomyce, Flavobacterium }\end{array}$ \\
\hline
\end{tabular}

${ }^{1}$ CFB denotes the bacterial group of Fibrobacterium, Flavobacterium, and Proteobacteria (CFB). ${ }^{2}$ HGC denotes bacterial group whose DNA has higher G and C DNA bases than A and $\mathrm{T}$ bases, as compared to other bacteria. ${ }^{3}$ LGC denotes the bacterial group whose DNA typically has fewer G and C DNA bases than A and T bases in comparison with other bacteria. 


\subsection{Bacteria and Archaea}

At the end of the 19th century, Christner [72] analyzed the Guliya ice cores from the Tibetan Plateau glaciers and found that the number of bacteria in them reached 180 cells/mL. Microbial diversity research was also subsequently conducted on Malan Glacier, Urumqi Glacier No. 1 in Tianshan Mountains and Dongkemadi Glacier on the Tibetan Plateau [72,75,84]. The number and major groups of bacteria in the ice cores varied in the different glaciers. The microorganisms in the Malan ice core were mainly Alphaproteobacteria, Betaproteobacteria, Gammaproteobacteria, and Fibrobacterium/Flavobacterium/Proteobacteria (CFB), with a total amount of 50-410 cells/mL, and the culturable microorganisms were $0-85 \mathrm{CFU} / \mathrm{mL}$ [73]. Tianshan Glacier No. 1 had a higher total number of microorganisms $\left(10^{3}-10^{5}\right.$ cells $\left./ \mathrm{mL}\right)$ compared to Malan Glacier [76]. The dominant taxa were found to be Alphaproteobacteria, Betaproteobacteria, Gammaproteobacteria, CFB, high $\mathrm{G}+\mathrm{C} \%$ bacteria (HGC), and low G+C Gram-positive bacteria (LGC) [76,88]. The culturable microorganisms in the Muztagata ice cores from the Pamir Plateau ranged from 9 to $96 \mathrm{CFU} / \mathrm{mL}$ with main taxa of Alphaproteobacteria, Betaproteobacteria, Cryobacteria, CFB, and HGC [75]. It can be seen that although there are differences in the microorganisms in the different glacial ice cores, there are also commonalities, which may be because microorganisms in ice cores mainly originate from atmospheric deposition. The atmospheric deposition in different periods may drive the different bacterial abundances and community structures at different ice core depths. For example, the composition of the bacterial taxa varied at four depths in the Malan ice core: Alphaproteobacteria, Betaproteobacteria, and Gammaproteobacteria (35 m); Betaproteobacteria (64 m); Gammaproteobacteria, CFB, Marinobacter, and agricultural soil bacterium (70 $\mathrm{m})$; and Betaproteobacteria (82 $\mathrm{m}$ ) [74]. The number of culturable bacteria in the Muztagata ice cores also varied with depth in the cores, and the variations were few and small at depths of $0-2.7,3.0-5.5,12.5-14.7$, and $16.0-17.7 \mathrm{~m}$, while the number of culturable bacteria (2 to $56 \mathrm{CFU} / \mathrm{mL}$ ) was greater at depths of 8-9.2 $\mathrm{m}$ [75].

With the continuous development of biomolecular information technology, microbial studies of glacier surface ice and snow have gradually developed, and the bacterial taxa present have been identified, including Alphaproteobacteria, Betaproteobacteria, Actinobacteria, Bacteroidetes, Firmicutes, Flavobacterium, and Cyanobacteria [81,85]. As the important autotrophic microbes, Oscillatoriales and Chroococcales were the main orders of cyanobacteria in the glacial surface, which could be found in the cryoconites of Urumqi Glacier No.1 and Yushugou Glacier [77,78]. The CFB and Proteobacteria taxa were dominant in the snow pits of the Miaoergou glacier in the Tianshan Mountains, while Actinobacteria was the dominant bacterial group in the snow samples from ZhuoAoyou on the Tibetan Plateau $[88,89]$. Alphaproteobacteria was the dominant culturable bacterial group, accounting for 52\%, isolated from the snow pits on Yulong Snow Mountain [87]. However, the dominant taxon in the surface snow and meltwater from Qiyi Glacier in the Qilian Mountains was Bacteroidetes [88]. This shows that the geographic location of the glacier has an impact on the bacterial community structure because of the distinctly different climatic and nutritional conditions [94,95]. In addition, the seasons also led to changes in the number of bacteria and the community's structure; e.g., the number of bacteria in snow deposited in summer $\left(2.3 \times 10^{4}\right.$ cells $\left./ \mathrm{mL}\right)$ was much higher than that in the snow deposited in winter $\left(6.9 \times 10^{3}\right.$ cells $\left./ \mathrm{mL}\right)$ in Rongbuk Glacier on Mt. Qomolangma [86]. Archaea have a lower diversity in glacier forelands and have received more research attention because of their important role in biogeochemical cycles, especially that of methane [96]. Euryarchaeota, Crenarchaeota, and Thaumarchaeota are the three dominant archaea phyla in glacier forelands, and they can withstand the low temperatures and remain active, but reports of archaea in glacial ice and snow environments in China are still rare [97-99].

Microbial activity and diversity are closely related to climatic factors such as temperature. Environmental changes induced by glacial retreat due to global warming are the main cause of the varied distribution of microbial communities in glacial retreat areas [100]. The microbial community in the glacier retreat area is dominated by bacterial communities, and 
archaea only account for a very small proportion [101]. Yue et al. reported that there was no correlation between the culturable bacteria and retreat time in the Zadang glacier foreland in the Nianqing Tanggula Mountains [102], while the number of culturable bacteria in the Tanggula Dongkemadi Glacier and Tianshan Glacier No. 1 increased with increasing glacier retreat time [103,104]. Focusing on Tianshan Glacier No. 1, we found that the copy number and microbial $\alpha$-diversity of the soil bacteria and archaea increased with increasing retreat age, and the relative abundance of the Bacillus phylum was found to increase, as well [105]. The abundances and community structure of the microorganisms shifted due to climate warming, and they generally exhibited positive correlations with the retreat time. However, because of the climate and environmental heterogeneity, there are some exceptions [106]. Further study is needed to clarify the underlying reasons for the specific successional changes in glacier microbiomes.

\subsection{Fungi}

Compared with bacteria and archaea, fungi are rare in the glacier surface and can be more easily found in the glacier forelands [107]. The dominant fungal phyla in the retreat area are Ascomycota and Basidiomycota [90,108,109]. There are also geographical differences in the community structure of glacial fungi; for example, the fungi in Himalayan glaciers include the genus Lemonniera and species Tetracladium nainitalense (Sati and P. Arya) and Thelebolus microsporus (Berk. and Broome) [69,108]; those in the Tibetan Plateau glaciers include Phoma sclerotioides (Preuss ex Sacc.), Pseudogymnoascus pannorum (Minnis and D.L. Lindner), Psychrophila antarctica (M.M. Wang and Xing Z. Liu), P. lutea (M.M. Wang and Xing Z. Liu), P. olivacea (M.M. Wang and Xing Z. Liu), Tetracladium ellipsoideum (M.M. Wang and Xing Z. Liu), T. globosum (M.M. Wang and Xing Z. Liu), and T. psychrophilum (M.M. Wang and Xing Z. Liu) [69,109]. In addition, differences in the structure of the fungal communities have been observed in different locations in the same glacier. The dominance of Basidiomycota and Ascomycota in Tianshan Glacier No. 1 is consistent with the dominant fungal taxa in the Hailuogou Glacier [91]. At the genus level, Rhodotorula and Leucosporidium dominate the glacier surface, but the unique genus Cladosporium also exists here. The genus Aureobasidium is unique to the sediment layer at the bottom of the glacier, and the dominant genera are Aspergillus and Simplicillium [110].

\subsection{Viruses}

Viruses are not only important drivers of microbial evolution due to their unique mode of survival and reproduction, but they also play important roles in the cycling of nutrients and organic matter in ecosystems. Because of the fragile, low biodiversity, and short biological chains in glacial ecosystems, viruses in glaciers have a more significant impact on their material cycles and microbial community survival [111]. Viruses have been found in relatively high abundances and diversity in the South and Arctic glaciers and the Greenland glaciers, and a high virus-to-bacteria ratio has been reported [112]. Analysis of their genetic information has revealed that there were 33 different viral species, including four known genera and 28 unknown genera, in the ice cores from Guria Glacier on the Tibetan Plateau. In addition, genetic prediction analysis revealed that 18 viral species were closely related to the number of multiple bacteria in the ice cores [113]. Viruses in the cryosphere may be released due to climate change, permafrost thawing, and glacier retreat. Based on an average glacier virus-to-bacteria ratio of 30 to 1, the amount of viruses released from Arctic glaciers into the downstream environment could be up to approximately $10^{23}$, which has a significant impact on downstream ecosystems $[114,115]$. The study of cryosphere viruses in China and around the world is still in its infancy. The impacts of these released viruses and how to cope with the possible threat under climate warming are important research directions for the future. 


\section{Involvement of Glacier Microbes in Carbon Cycle}

According to statistics, approximately $6 \mathrm{Pg}$ of organic carbon is stored in glaciers worldwide, which could be released after glacier retreat due to the increased temperature and increased microbial activity [116]. The impacts on the ecosystems and the feedback on climate change due to the increased carbon release from the glacier ecosystem must be assessed. It is estimated that $0.58 \pm 0.07 \mathrm{Tg}$ of dissolved organic carbon would be released from meltwater of mountain glaciers, which would account for about $56 \%$ of dissolved organic carbon loss from all glaciers in the world [116-118]. In addition, as glaciers melt, subglacial sediments are gradually exposed and large amounts of carbon are released in different forms, further influencing the balance of the original global carbon cycle [119].

Glacier forelands provide an ideal study area and are a spatial representative of the temporal changes in important biogeochemical processes such as the accumulation of soil organic carbon (SOC) $[120,121]$. Expect for external input such as supraglacial input and aerial deposition, biological activity is the major source of the nutrients in glacier forelands [120,122]. Thus, there are three distinct carbon sources in glacier forelands: the ancient organic pools originating from under the glacier, exogenous deposition such as soot particles, and the primary production of vegetation and autotrophic microorganisms [122]. Soil development requires the accumulation of SOC, but the speed of soil development is significantly affected by the climate conditions and regional geographic environment. The microbial biogenic carbon content varies significantly with successional age, ranging from 4.78 to $145.53 \mathrm{mg} / \mathrm{kg}$ in the soils exposed by the retreat of Hailuogou Glacier, which is a typical temperate glacier in China [123]. Shrubs appeared in less than 30 years in the foreland of Hailuogou Glacier [124]. Meadow vegetation began to colonize the area after the soil had been exposed for about 20 years in the forelands of Tianshan Glacier No. 1, and in more than 10 years for the Laohugou Glacier [125].

As the dominant undertaker of life activities in the fragile glacier ecosystem, microorganisms are the main contributors to the carbon cycles, and they have various metabolism and fixation capacities, which determine the dynamic storage of the carbon pool before the emergence of vegetation $[8,126]$. Traditionally, detection of enzyme activity and microbial culture methods have been used to study the biogeochemical processes mediated by microbial communities [127-129]. With the development of high-throughput sequencing and the microarray-based metabolic Geochip, a better understanding of the relationships between element biogeochemical cycles and microorganisms can be obtained from the microbial community's composition, as well as the diversity and abundance of the functional genes [130].

Under the low temperature, high UV exposure, and unstable water conditions of the glacier ecosystem, microorganisms, including fungi, bacteria, and archaea, in glacier forelands are characterized by strong carbon metabolism abilities [131]. Zhu et al. [92] determined that the microbial community in the Laohugou Glacier can use amino acids, carbohydrates, carboxylic acids, and amines as metabolic substrates using the BiologEco microporous plate method. By detecting the soil enzymes, such as urease, sucrase, protease, polyphenol oxidase, catalase, and dehydrogenase, Wu et al. [127] found that the enzyme activity increased as the exposure time increased in the foreland of Tianshan Glacier No. 1, indicating active microbial metabolism. This is consistent with the increased microbial activity during the soil chronosequence of the foreland of Tianshan Glacier No. 1 [132]. Sanyal et al. [133] found that the microbial communities in the Himalayan region are able to utilize more diverse types of carbonaceous substrates compared to those in the Antarctic region. The effects of the heterogeneity of mountain glaciers on the responses and feedback of microbial communities must be studied further.

Nearly all microorganisms need to decompose carbon nutrients to survive; only photoautotrophs such as Cyanobacteria and chemoautotrophs and some members of Alphaproteobacteria can synthesize carbon compounds independently through utilization of inorganic carbon such as $\mathrm{CO}_{2}$ and bicarbonate $[121,134,135]$. Cyanobacteria are important contributors to the carbon in glacier forelands and cryconite $[76,133,136]$. For example, 
Cyanobium (Synechococcales), Trichormus, and Nostoc (Nostocales) can fix $\mathrm{CO}_{2}$ into organic carbon compounds using light energy via the Calvin cycle (CBB cycle). This typical carbon fixation pathway utilizes one molecule of $\mathrm{CO}_{2}$ and ribulose 1, 5-disphoshate to synthesize third molecules of triose phosphate $[137,138]$. Some members of Cyanobacteria can upregulate the carbon concentration to improve the carbon fixation ability [134]. Chemoautotrophs such as sulfate-reducing bacteria and Chlorobiales have been found in Antarctic soils [135], and they can utilize organic carbon through the reductive tricarboxylic acid cycle (rTCA cycle). This pathway converts four molecules of $\mathrm{CO}_{2}$ into one molecule of oxalacetate [137]. The reductive acetyl-CoA pathway (WL cycle) and the hydroxypropionate bicycle (3HP cycle) convert two molecules of $\mathrm{CO}_{2}$ into acetic acid or glyoxylate [136], and they have been found to occur in Antarctica based on detection of Chloroflexi, Armatimonadetes, and Nitrospirae $[119,139]$. Generally, the Calvin cycle is the main pathway in the surface environments of mountain glaciers, such as in the glacial runoff of Qiangyong and Satrundi glaciers on the Tibetan Plateau [140,141]. Based on bioinformation analysis, Actinobacteria, Cyanobacteria, and Proteobacteria, which are also the main microbial groups found in Chinese glaciers, are the dominant carbon sequestration microbial groups [140,142-144]. The mean relative abundance of Actinobacteria, Cyanobacteria, and Proteobacteria was found to be higher in Tibetan Plateau glaciers than in the South and Arctic glaciers, which implies a higher carbon fixation ability in this area [119]. The assessment of the rate of carbon sequestration is key to understanding the carbon cycle; however, few relevant studies have been conducted on the Chinese glacier ecosystem.

\section{Concluding Remarks}

At present, climate change has accelerated glacier ablation, accompanied by a large amount of glacier foreland exposure. With the abundant carbon storage and more intense microbial activities, not only have microbial succession and soil development received wide attention, but changes in the carbon cycle in glacier forelands have also been intensively studied, such as carbon sources [8,122], the carbon release rate [145], and the dynamic processes involving carbon [146,147].

Climate warming will have direct and indirect effects on microbial communities, including changes in the microbial community structures, the accelerated release of $\mathrm{CO}_{2}$, and the indirect impact of changes in the soil properties [148]. Based on field experiments and indoor simulation experiments, the carbon loss would be intensified as the temperature increases due to the more actively microbial activities [149-151]. Higher carbon fluxes have been detected in short-term warming experiments compared with long-term warming experiments [152], which is related to the lack of labile carbon [153], the low carbon utilization rate [154], and changes in the thermal adaptability of microorganisms [155,156].

Furthermore, the biogeochemical cycle in the glacier ecosystem is mediated by microorganisms, which are affected by the environmental conditions, such as nutrient limitations [157]. Jiang et al. [158] investigated the microbial processes and nutrient limitations and also found that carbon and nitrogen are the main limiting nutrients in the early succession stage in Hailuogou Glacier, followed by a shift to phosphorus in the later stages. Climate warming and the retreat time affect the soil properties and microbial community, which can result in positive or negative feedback.

As one of the indicators of climate change, glacier microbiomes and their response to climate warming can provide a better understanding of glacier ecosystems and the effects of climate warming. At present, although a series of results have been achieved regarding microbial diversity and community structure, research on Chinese glacial microbiomes still needs to be strengthened. Under the context of climate change, future sustained research, including the following topics, is required.

1. Response of glacial microbes to climate change

Microbial responses to climate change are complex. The microbial response to climate warming varies in the different types of glaciers. In particular, mountain glaciers have a higher environmental heterogeneity, so enhancing the research on these glaciers may 
improve our understanding of global glacier microbes. In addition, ancient viruses that lie dormant in glaciers may be gradually released with the melting of glaciers. Whether they are still infectious and pose a great threat to glacial ecosystems locally or globally is an issue that needs to be explored.

2. Evolutionary and biogeographical studies of glacial microbiomes

Many studies have found that glacial microorganisms mostly originate from atmospheric deposition, and they subsequently undergo gradual adaptation over time to become glacier-specific, but there are different opinions on this subject. Therefore, where and how glacial microbes originate, how they colonize, and their environmental and evolutionary drivers need to be studied further. The microbial diversity in the glaciers in China has both uniqueness and similarities compared to glaciers elsewhere in the world. Whether there is a certain pattern in the distribution of glacial microbes across the country or even globally must be determined. All of these issues are related to the origin and evolution of glacial microorganisms and biogeography.

3. Glacial microbes and geochemical cycles

At present, research on the mediation of the geochemical cycles by glacial microbiomes in China is in the preliminary stage. More attention is devoted to the carbon and nitrogen cycles, while other elements, such as sulfur, phosphorus, and metals, have been studied less. With the retreat of glaciers, various elements contained in the glaciers are gradually being released, and their effects on glacial microorganisms and the underlying mechanisms of these effects need to be studied further.

4. Glacial microbial diversity and microbial resources

Glacier microorganisms often have their own unique metabolic characteristics and products, such as protease producing low-temperature resistant bacteria, low-temperature amylase-producing strains, and purple pigment synthesized strains [159-161]. The diversity of glacier microorganisms is rapidly decreasing as a result of climate warming, which suggests that the biodiversity of the environment-specific microorganisms in glaciers will also decrease. We recognize the effects of climate change on glacier microbiomes and their feedback; however, we know far less about this issue. It is urgent to strengthen research on glacier microbiomes to conserve the biodiversity and these unique microbial resources.

Author Contributions: Conceptualization, A.M., J.Z. and G.Z.; original draft preparation, A.M. and J.Z.; review and editing, G.L. and X.Z. All authors have read and agreed to the published version of the manuscript.

Funding: This work was supported by the Second Tibetan Plateau Scientific Expedition and Research Program (2019QZKK0402, 2019QZKK0307) and the National Key Research and Development Program of China (2018YFA0901200).

Institutional Review Board Statement: Not applicable.

Informed Consent Statement: Not applicable.

Data Availability Statement: Not applicable.

Conflicts of Interest: The authors declare no conflict of interest.

\section{References}

1. Qin, D.; Yao, T.; Ding, Y.; Ren, J. Establishment and Significance of the Scientific System of Cryospheric Science. Bull. Chin. Acad. Sci. 2020, 35, 394-406. [CrossRef]

2. Liu, S.; Yao, X.; Guo, W.; Xu, J.; Shangguan, D.; Wei, J.; Bao, W.; Wu, L. The Contemporary Glaciers in China Based on the Second Chinese Glacier Inventory. Acta Geogr. Sin. 2015, 70, 3-16. [CrossRef]

3. Boetius, A.; Anesio, A.M.; Deming, J.W.; Mikucki, J.A.; Rapp, J.Z. Microbial Ecology of the Cryosphere: Sea Ice and Glacial Habitats. Nat. Rev. Microbiol. 2015, 13, 677-690. [CrossRef]

4. Eva, G.; Cristna, C. Glaciers and Ice Sheets as Analog Environments of Potentially Habitable Icy Worlds. Front. Microbiol. 2017, 8, 1407. [CrossRef] 
5. Makowska, N.; Zawierucha, K.; Mokracka, J.; Koczura, R. First Report of Microorganisms of Caucasus Glaciers (Georgia). Biologia 2016, 71, 620-625. [CrossRef]

6. Martinez-alonso, E.; Pena-perez, S.; Serrano, S.; Garcia-lopez, E. Taxonomic and Functional Characterization of a Microbial Community from a Volcanic Englacial Ecosystem in Deception. Sci. Rep. 2019, 9, 12158. [CrossRef]

7. Margesin, R.; Collins, T. Microbial Ecology of the Cryosphere (Glacial and Permafrost Habitats): Current Knowledge. Appl. Microbiol. Biotechnol. 2019, 103, 2537-2549. [CrossRef]

8. Stibal, M.; Šabacká, M.; Žárský, J. Biological Processes on Glacier and Ice Sheet Surfaces. Nat. Geosci. 2012, 5, 771-774. [CrossRef]

9. Xu, H.; Wang, F.; Li, T.; Wu, X. A Review of Freezing-Thawing Cycle Effects on Key Processes of Soil Nitrogen Cycling and the Underlying Mechanisms. Acta Ecol. Sin. 2020, 40, 3168-3182. [CrossRef]

10. Zarsky, J.D.; Stibal, M.; Hodson, A.; Sattler, B. Large Cryoconite Aggregates on a Svalbard Glacier Support a Diverse Microbial Community Including Ammonia-Oxidizing Archaea. Environ. Res. Lett. 2013, 8, 035044. [CrossRef]

11. Ambrosini, R.; Musitelli, F.; Navarra, F.; Tagliaferri, I.; Gandolfi, I.; Bestetti, G.; Mayer, C.; Minora, U.; Azzoni, R.S.; Diolaiuti, G.; et al. Diversity and Assembling Processes of Bacterial Communities in Cryoconite Holes of a Karakoram Glacier. Environ. Microbiol. 2017, 73, 827-837. [CrossRef] [PubMed]

12. Liu, Y.; Vick-majors, T.J.; Priscu, J.C.; Yao, T.; Kang, S.; Liu, K.; Cong, Z.; Xiong, J. Biogeography of Cryoconite Bacterial Communities on Glaciers of the Tibetan Plateau. FEMS Microbiol. Ecol. 2017, 93, 10. [CrossRef] [PubMed]

13. Lutz, S.; Mccutcheon, J.; Mcquaid, J.B.; Benning, L.G. The Diversity of Ice Algal Communities on the Greenland Ice Sheet as Revealed by Oligotyping. Microb. Genomics 2018, 4, e000159. [CrossRef] [PubMed]

14. Kadow, C.; Hall, D.M.; Ulbrich, U. Artificial Intelligence Reconstructs Missing Climate Information. Nat. Geosci. 2020, 13, 408-413. [CrossRef]

15. Arias, P.A.; Bellouin, N.; Coppola, E.; Jones, R.G.; Krinner, G.; Marotzke, J.; Naik, V.; Palmer, M.D.; Plattner, G.-K.; Rogelj, J.; et al. Technical Summary. In Climate Change 2021: The Physical Science Basis. Contribution of Working Group I to the Sixth Assessment Report of the Intergovernmental Panel on Climate Change; Cambridge University Press: Cambridge, UK; New York, NY, USA, 2021; pp. $42-44$.

16. Steffen, W.; Rockström, J.; Richardson, K.; Lenton, T.M.; Folke, C.; Liverman, D.; Summerhayes, C.P.; Barnosky, A.D.; Cornell, S.E.; Crucifix, M.; et al. Trajectories of the Earth System in the Anthropocene. Proc. Natl. Acad. Sci. USA 2018, 115, 8252-8259. [CrossRef] [PubMed]

17. Veettil, B.K.; Kamp, U. Global Disappearance of Tropical Mountain Glaciers: Observations, Causes, and Challenges. Geosciences 2019, 9, 196. [CrossRef]

18. Yao, T.; Xue, Y.; Chen, D.; Chen, F.; Thompson, L.; Cui, P.; Koike, T.; Lau, W.K.-M.; Lettenmaier, D.; Mosbrugger, V.; et al. Recent Third Pole's Rapid Warming Accompanies Cryospheric Melt and Water Cycle Intensification and Interactions between Monsoon and Environment: Multidisciplinary Approach with Observation, Modeling and Analysis. Bull. Am. Meteorol. Soc. 2019, 100, 423-444. [CrossRef]

19. Zemp, M.; Huss, M.; Thibert, E.; Eckert, N.; McNabb, R.; Huber, J.; Barandun, M.; Machguth, H.; Nussbaumer, S.U.; Gärtner-Roer, I.; et al. Global Glacier Mass Changes and Their Contributions to Sea-Level Rise from 1961 to 2016. Nature 2019, 568, 382-386. [CrossRef] [PubMed]

20. Guo, W.; Liu, S.; Xu, J.; Wu, L.; Shangguan, D.; Yao, X.; Wei, J.; Bao, W.; Yu, P.; Liu, Q.; et al. The Second Chinese Glacier Inventory: Data, Methods and Results. J. Glaciol. 2015, 61, 357-372. [CrossRef]

21. Wang, Z.; Su, H. Glaciers in the World and China: Distribution and Their Significance as Water Resources. J. Glaciol. Geocryol. 2003, 25, 498-503. [CrossRef]

22. Rime, T.; Hartmann, M.; Brunner, I.; Widmer, F.; Zeyer, J.; Frey, B. Vertical Distribution of the Soil Microbiota along a Successional Gradient in a Glacier Forefield. Mol. Ecol. 2015, 24, 1091-1108. [CrossRef] [PubMed]

23. Frey, B.; Rime, T.; Phillips, M.; Stierli, B.; Hajdas, I.; Widmer, F.; Hartmann, M. Microbial Diversity in European Alpine Permafrost and Active Layers. FEMS Microbiol. Ecol. 2016, 92, fiw018. [CrossRef] [PubMed]

24. Botnen, S.; Mundra, S.; Kauserud, H.; Eidesen, P. Glacier Retreat in the High Arctic: Opportunity or Threat for Ectomycorrhizal Diversity? FEMS Microbiol. Ecol. 2020, 96, fiaa171. [CrossRef] [PubMed]

25. Shi, Y.; Zheng, B.; Yao, T. Glaciers and Environments during the Last Glacial Maximum (LGM) on the Tibetan Plateau. J. Glaciol. Geocryol. 1997, 19, 97-113.

26. Shi, Y.; Ren, B.; Xie, Z. Progress of Glaciology Research in China in the Past 30 Years. J. Glaciol. Geocryol. 1979, 2, 1-6.

27. Huang, M.; Shi, Y. Progress in the Study on Basic Features of Glaciers in China in the Last Thirty Years. J. Glaciol. Geocryol. 1988, 10, 228-237.

28. Shen, Y.; Chang, X.; Li, Y.; Wang, C. The Special of Chinese Glaciers. For. Humankind 2018, 12, $192-207$.

29. Zemp, M.; Haeberli, W.; Hoelzle, M.; Paul, F. Alpine Glaciers to Disappear within Decades? Geophys. Res. Lett. 2006, 33, L13504. [CrossRef]

30. Li, Z.; He, Y.; Pu, T.; Jia, W.; He, X.; Pang, H.; Zhang, N.; Liu, Q.; Qiao, L.; Wang, S.; et al. Changes of Climate, Glaciers and Runoff in China's Monsoonal Temperate Glacier Region during the Last Several Decades. Quat. Int. 2010, 218, 13-28. [CrossRef]

31. Xu, X.; Pan, B.; Hu, E.; Li, Y.; Liang, Y. Responses of Two Branches of Glacier No. 1 to Climate Change from 1993 to 2005, Tianshan, China. Quat. Int. 2011, 236, 143-150. [CrossRef] 
32. Sun, M.; Li, Z.; Yao, X.; Jin, S. Rapid Shrinkage and Hydrological Response of a Typical Continental Glacier in the Arid Region of Northwest China-Taking Urumqi Glacier No. 1 as an Example. Ecohydrology 2013, 6, 909-916. [CrossRef]

33. Zhang, M.; Wang, S.; Li, Z.; Wang, F. Variation of Glacier Area in China against the Warming in the Past 50 Years. Acta Geogr. Sin. 2011, 66, 1155-1165.

34. Zhao, H.; Wang, X.; Zhao, X.; Guo, W.; Liu, S.; Wei, J.; Zhang, Y. Analysis of Glacier Changes in China from 2008 to 2018. J. Glaciol. Geocryol. 2021, 43, 976-986. [CrossRef]

35. Duan, J.; Wang, L.; Ren, J.; Li, L. Progress in Glacier Variations in China and Its Sensitivity to Climatic Change during the Past Century. Prog. Geogr. 2009, 28, 231-237. [CrossRef]

36. Feng, T.; Liu, S.; Xu, J.; Guo, W.; Wei, J.; Zhang, Z. Glacier Change of the Yarkant River Basin from 1968 to 2009 Derived from the First and Second Glacier Inventories of China. J. Glaciol. Geocryol. 2015, 37, 1-13. [CrossRef]

37. Xie, Z.C.; Wang, X.; Feng, Q.H.; Kang, E.; Liu, C.H.; Li, Q.Y. Modeling the Response of Glacier Systems to Climate Warming_Taking Glaciers in China as an Example. Res. Soil Water Conserv. 2005, 12, 313-316. [CrossRef]

38. Su, Z.; Shi, Y. Response of Monsoonal Temperate Glaciers in China to Global Warming since the Little Ice Age. J. Glaciol. Geocryol. 2000, 22, 223-229. [CrossRef]

39. Wang, P.; Li, Z.; Luo, S.; Bai, J.; Huai, B.; Wang, F.; Li, H.; Wang, W.; Wang, L. Five Decades of Changes in the Glaciers on the Friendship Peak in the Altai Mountains, China: Changes in Area and Ice Surface Elevation. Cold Reg. Sci. Technol. 2015, 116, 24-31. [CrossRef]

40. Huai, B.; Li, Z.; Wang, F.; Wang, P. Variation of Glaciers in the Sawuer Mountain within Chinese Territory during 1959-2013. J Glaciol. Geocryol. 2015, 37, 1141-1149. [CrossRef]

41. Zhang, C.; Yao, X.; Liu, S.; Zhang, D.; Xu, J. Variation of Glacier Length in the Altun Mountains during 1970-2016. J Glaciol. Geocryol. 2021, 43, 49-60. [CrossRef]

42. Zhao, C.; Liang, J.; Wang, J.; Yang, L.; Zhang, S. Remote Sensing Analysis of Glacier Dynamic Changes in Parlung Zangbo River. Sci. Technol. Eng. 2019, 19, 56-62. [CrossRef]

43. Liu, J.; Yao, X.; Liu, S.; Guo, W.; Xu, J. Glacier Changes in the Gangdisê Mountains from 1970 to 2016. Acta Geogr. Sin. 2019, 74, 1333-1344. [CrossRef]

44. Zhang, W.; Wang, N.; Li, X.; Liu, K. Glacier Changes and Its Response to Climate Change in the Gilgit River Basin, Western Karakorum Mountains over the Past 20 Years. Mt. Res. 2019, 37, 347-358. [CrossRef]

45. Zhang, Z.; Xu, J.; Liu, S.; Guo, W.; Wei, J.; Feng, T. Glacier Changes since the Early 1960s, Eastern Pamir, China. J. Mt. Sci. 2016, 13, 276-291. [CrossRef]

46. Jia, B.; Hou, S.; Wang, Y. Variation of Glaciers at Zangser Kangri on the Qiangtang Plateau during 1971-2015. J. Glaciol. Geocryol. 2020, 42, 307-317. [CrossRef]

47. Sun, M.; Liu, S.; Yao, X.; Guo, W.; Xu, J. Glacier Changes in the Qilian Mountains in the Past Half Century: Based on the Revised First and Second Chinese Glacier Inventory. Acta Geogr. Sin. 2015, 70, 1402-1414. [CrossRef]

48. Wang, Y.; Li, J.; Wu, L.; Guo, L.; Li, J. Using Remote Sensing Images to Monitor the Glacier Changes in Qilian Mountains during 1987-2018 and Analyzing the Impact Factors. J. Glaciol. Geocryol. 2020, 42, 344-356. [CrossRef]

49. Wang, P.; Li, Z.; Gao, W. Rapid Shrinking of Glaciers in the Middle Qilian Mountain Region of Northwest China during the Last 50 Years. J. Earth Sci. 2011, 22, 539-548. [CrossRef]

50. Wang, P.; Li, Z.; Yu, G.; Li, H.; Wang, W.; Huai, B.; Zhou, P.; Jin, S.; Wang, L.; Zhang, H. Glacier Shrinkage in the Daxue and Danghenan Ranges of the Western Qilian Mountains, China, from 1957 to 2010. Environ. Earth Sci. 2016, 75, 127. [CrossRef]

51. Cai, Y.; Huang, W.; Teng, F.; Gu, S. Effects of Changing Climate on Glacier Shrinka Age and River Flow in the Upper Heihe River Basin, China. J. Coast. Res. 2014, 68, 121-128. [CrossRef]

52. Chen, H.; Li, Z.Q.; Wang, P.Y.; Lai, Z.P.; Chen, R.S.; Huai, B.J. Five Decades of Glacier Changes in the Hulugou Basin of Central Qilian Mountains, Northwest China. J. Arid Land 2015, 7, 159-165. [CrossRef]

53. Liu, Y.; Qin, X.; Chen, J.; Li, Z.; Wang, J.; Du, W.; Guo, W. Variations of Laohugou Glacier No. 12 in the Western Qilian Mountains, China, from 1957 to 2015. J. Mt. Sci. 2018, 15, 25-32. [CrossRef]

54. Ou, J.; Xu, L.; Pu, T. Glacier Change and Its Response to Climate Change in the Que'er Mountains, 1987-2016. J. Glaciol. Geocryol. 2021, 43, 36-48. [CrossRef]

55. Wang, Y.; Zhao, J.; Li, Z.; Zhang, M. Glacier Changes in the Sawuer Mountain during 1977-2017 and Their Response to Climate Change. J. Nat. Resour. 2019, 34, 802-814. [CrossRef]

56. Xing, W.; Li, Z.; Zhang, H.; Zhang, M.; Liang, P.; Mu, J. Spatial-Temporal Variation of Glacier Resources in Chinese Tianshan Mountains since 1959. Acta Geogr. Sin. 2017, 72, 1594-1605. [CrossRef]

57. Meng, Y.; Li, Z.; Xu, C.; Huai, B. Glacier Change of Western China since the Little Ice Age: A Case of the Urumqi River Watershed. Arid L Geogr. 2016, 39, 486-494. [CrossRef]

58. Wang, W.; Li, K.; Gao, J. Monitoring Glacial Shrinkage Using Remote Sensing and Site-Observation Method on Southern Slope of Kalik Mountain, Eastern Tian Shan, China. J. Earth Sci. 2011, 22, 503-514. [CrossRef]

59. Huang, X.; Bao, A.; Guo, H.; Meng, F.; Zhang, P. Change of Typical Glaciers and Its Response to Meteorological Factors in the Eastern Tianshan Mountains in China in Recent 20 Years. Arid Zone Res. 2017, 34, 870-880. [CrossRef]

60. Zhao, J.; Mansur, S.; Mailikai, A.; Nijiate, Y. Changing Rates of Glacier in Tomur National Nature Reserve from 1992 to 2017 ZHAO. Arid Zone Res. 2020, 37, 1079-1086. [CrossRef] 
61. Li, H.; Wang, P.; Li, Z.; Wang, P.; Xu, C.; Liu, S.; Jin, S.; Zhang, Z.; Xu, L. Research on the Changes of the Urumqi Glacier No. 1, Tianshan Mountains Based on Multi-Source Remote Sensing Data. J. Glaciol. Geocryol. 2021, 43, 1018-1026. [CrossRef]

62. Ji, Q.; Liu, R.; Yang, T. Glacier Variations in the Himalayas during 1990-2015 JI. Geogr. Res. 2020, 39, 2403-2414. [CrossRef]

63. Wu, K.; Liu, S.; Guo, W. Glacier Variation and Its Response to Climate Change in the Mount Namjagbarwa from 1980 to 2015. J. Glaciol. Geocryol. 2020, 42, 1115-1125. [CrossRef]

64. Wang, J.; Yang, T.; Ji, Q.; Hu, F. Change of the Modern Glaciers in the Eastern Himalaya near China and Bhutan Border Area from 1990 to 2015. Arid L Geogr. 2019, 42, 542-550. [CrossRef]

65. Kou, Y.; Wang, N.; Chen, A.; Liu, K. Monitoring Variation of Glaciers Based on Remote Sensing Images in the Chenab Basin, Western-Himalaya, 1993 2016. Remote Sens. Technol. Appl. 2020, 35, 712-722. [CrossRef]

66. Lhakpa, D.; Yu, X. Study on the Variation of Chema Yongdrung Glacier in Tibet Using Remote Sensing during 1976-2019. Plateau Sci. Res. 2020, 4, 17-29, 54. [CrossRef]

67. Li, C.; Jing, Z.; He, X. Remote Sensing Monitoring of Glacier Variation in Geladandong, Source Regions of the Yangtze River from 1986 to 2015. J. Glaciol. Geocryol. 2021, 43, 405-416. [CrossRef]

68. Anesio, A.M.; Lutz, S.; Chrismas, N.A.M.; Benning, L.G. The Microbiome of Glaciers and Ice Sheets. NPJ Biofilms Microbiomes 2017, 3, 10. [CrossRef]

69. Li, S.; Chen, T.; Zhang, W.; Liu, G. Cryomicrobiology: Retrospect and Prospect. J. Glaciol. Geocryol. 2019, 41, 1221-1234. [CrossRef]

70. Yao, T.; Qin, D.; Shen, Y.; Zhao, L.; Wang, N.; Lu, A. Cryospheric Changes and Their Impacts on Regional Water Cycle and Ecological Conditions in the Qinghai-Tibetan Plateau. Chin. J. Nat. 2013, 35, 179-186. [CrossRef]

71. Chen, Y.; Li, X.K.; Si, J.; Wu, G.J.; De Tian, L.; Xiang, S.R. Changes of the Bacterial Abundance and Communities in Shallow Ice Cores from Dunde and Muztagata Glaciers, Western China. Front. Microbiol. 2016, 7, 1716. [CrossRef]

72. Christner, B.C.; Mosley-thompson, E.; Thompson, L.G.; Zagorodnov, V.; Sandman, K.; Reeve, J.N. Recovery and Identification of Viable Bacteria Immured in Glacial Ice. Icarus 2000, 144, 479-485. [CrossRef]

73. Zhang, X.; Yao, T.; Ma, X.; Wang, N. Malan Glacier: Analysis of Microbial Signatures in a Deep Ice Core. Sci. China (Ser. D) 2001, 31, 295-299.

74. Xiang, S.; Yao, T.; An, L.; Li, Z.; Wu, G.; Wang, Y.; Xu, B.; Wang, J. The Relationship between the Structural Changes of Malan Ice Core Bacteria and Climatic Environment. Chin. Sci. Bull. 2004, 49, 1762-1769. [CrossRef]

75. Xiang, S.; Yao, T.; An, L.; Wu, G.; Xu, B.; Ma, X.; Li, Z.; Wang, J.; Yu, W. The Quantity Distribution of the Culturable Bacteria and the Change of the Main Bacterial Community Structure with Depth in The Muztagata Ice Core. Sci. China (Ser. D) 2005, 35, 252-262. [CrossRef]

76. Lin, J.; Zhang, X.; An, L.; Yao, T.; Li, Z.; Wang, F.; Xu, S. Study on the Diversity of Ice Core Bacteria in Tianshan Mountain. J. Glaciol. Geocryol. 2008, 3, 1033-1040.

77. Ni, X.; Qi, X.; Gu, Y.; Zheng, X.; Dong, J.; Ni, Y.; Cheng, G. Community Structure and Phylogenetic Analysis of Cyanobacteria in Cryoconite from Surface of the Glacier No.1 in the Tianshan Mountains. Acta Microbiol. Sin. 2014, 54, $1256-1266$.

78. Xu, H.; Li, Z.; Takeuchi, N.; Zhang, X.; Luo, S. Characteristics and Formation Analysis of Cryoconite Granules of Yushugou Glacier. Arid L Geogr. 2014, 37, 429-438. [CrossRef]

79. Liu, Y.; Yao, T.; Jiao, N.; Kang, S.; Huang, S.; Li, Q.; Wang, K.; Liu, X. Culturable Bacteria in Glacial Meltwater at $6350 \mathrm{~m}$ on the East Rongbuk Glacier, Mount Everest. Extremophiles 2009, 13, 89-99. [CrossRef]

80. Zhou, L.; Zhou, Y.; Hu, Y.; Cai, J.; Liu, X.; Bai, C.; Tang, X.; Zhang, Y.; Jang, K.S.; Spencer, R.G.M.; et al. Microbial Production and Consumption of Dissolved Organic Matter in Glacial Ecosystems on the Tibetan Plateau. Water Res. 2019, 160, 18-28. [CrossRef]

81. Li, Y.; Wang, J.; Sawut, G. Culturable Bacterial Diversity in Snow, Ice and Meltwater of the Yangbark Glacier, Muztag Ata. J. Glaciol. Geocryol. 2015, 37, 1634-1641. [CrossRef]

82. Segawa, T.; Takeuchi, N. Cyanobacterial Communities on Qiyi Glacier, Qilian Shan, China. Ann. Glaciol 2010, 51, 135-144. [CrossRef]

83. Xie, J.; Wang, N.; Chen, L.; Li, Q.; He, J.; Jiang, X.; Wu, X. Bacterial Diversity Recovered from Qiyi Glacier and Runoff, Qilian Mts. Chin. J. Environ. Sci. 2009, 30, 2735-2740.

84. Liu, Y.; Yao, T.; Jiao, N.; Tian, L.; Hu, A.; Yu, W.; Li, S. Microbial Diversity in the Snow, a Moraine Lake and a Stream in Himalayan Glacier. Extremophiles 2011, 15, 411-421. [CrossRef]

85. Xie, J.; Wang, N.; Pu, J.; Chen, L. Study of the Bacterial Diversity Recovered from Glacial Snow of the Northern Tibetan Plateau. J. Glaciol. Geocryol. 2009, 31, 342-349.

86. Liu, Y.; Yao, T.; Kang, S.; Jiao, N.; Zeng, Y.; Shi, Y.; Luo, T.; Jing, Z.; Huang, S. Microbial Community of Ice and Snow and Its Seasonal Variation in DongRongbu Glacier in Qomolangma Region. Chin. Sci. Bull. 2006, 51, 1287-1296. [CrossRef]

87. Ma, X.; Liu, W.; Hou, S.; Chen, T.; Qin, D. Bacterial Diversity and Community at Yulong Mountains and Their Relationship to Climatic and Environmental Changes. J. Lanzhou Univ. Nat. Sci. 2009, 45, 94-100. [CrossRef]

88. Liu, W.; Ma, X.; Hou, S.; Chen, T.; Qin, D. Study on Microbial Diversity and Community in Miaoergou Snow of East Tianshan Mountains and Their Relation to Climatic and Environmental Changes. Acta Microbiol. Sin. 2007, 47, 1019-1026. [CrossRef]

89. Tong, X.; Chen, F.; Yu, J.; Hua, S.; Ciren, S.; Jiangbai, L.; Wang, W.; Liang, Y.; Zheng, X.; Wang, J. Analysis of Bacterial Flora Structure and Diversity in ZhuoAoyou Peak (8201 m) Snow Cover. Chin. Sci. Bull. 2008, 53, 2216-2222. [CrossRef] 
90. Yang, G.L.; Hou, S.G.; Le Baoge, R.; Li, Z.G.; Xu, H.; Liu, Y.P.; Du, W.T.; Liu, Y.Q. Differences in Bacterial Diversity and Communities between Glacial Snow and Glacial Soil on the Chongce Ice Cap, West Kunlun Mountains. Sci. Rep. 2016, 6, 36548. [CrossRef]

91. Sun, H.; Wu, Y.; Zhou, J.; Bing, H. Variations of Bacterial and d Fungal Communities along a Primary Successional Chronosequence in the Hailuogou Glacier Retreat Area (Gongga Mountain, SW China). J. Mt. Sci. 2016, 13, 1621-1631. [CrossRef]

92. Zhu, Y.; Zhang, Y.; Chen, H.; Wang, Y.; Cao, F.; Sun, W.; Qi, X.; Zhao, Y. Soil Properties and Microbial Diversity at the Frontier of Laohugou Glacier Retreat in Qilian Mountains. Curr. Microbiol. 2020, 77, 425-433. [CrossRef]

93. Li, W.; Li, H.; Sun, W.; Ji, X.; Wei, Y. Diversity of Culturable Low-Temperature Bacteria in Vertical Climate Zones of Mingyong Glacier. Genomics Appl. Biol. 2019, 38, 2070-2077. [CrossRef]

94. Donhauser, J.; Frey, B. Alpine Soil Microbial Ecology in a Changing World. FEMS Microbiol. Ecol. 2018, 94, 1-31. [CrossRef]

95. Hultman, J.; Waldrop, M.P.; Mackelprang, R.; David, M.M.; McFarland, J.; Blazewicz, S.J.; Harden, J.; Turetsky, M.R.; McGuire, A.D.; Shah, M.B.; et al. Multi-Omics of Permafrost, Active Layer and Thermokarst Bog Soil Microbiomes. Nature 2015, 521, 208-212. [CrossRef]

96. Nauer, P.A.; Dam, B.; Liesack, W.; Zeyer, J.; Schroth, M.H. Activity and Diversity of Methane-Oxidizing Bacteria in Glacier Forefields on Siliceous and Calcareous Bedrock. Biogeosciences 2012, 9, 2259-2274. [CrossRef]

97. Boyd, E.S.; Skidmore, M.; Mitchell, A.C.; Bakermans, C.; Peters, J.W. Methanogenesis in Subglacial Sediments. Environ. Microbiol. Rep. 2010, 2, 685-692. [CrossRef]

98. Lopatina, A.; Medvedeva, S.; Shmakov, S.; Logacheva, M.D.; Krylenkov, V.; Severinov, K. Metagenomic Analysis of Bacterial Communities of Antarctic Surface Snow. Front. Microbiol. 2016, 7, 398. [CrossRef]

99. Christner, B.C.; Priscu, J.C.; Achberger, A.M.; Barbante, C.; Carter, S.P.; Christianson, K.; Michaud, A.B.; Mikucki, J.A.; Mitchell, A.C.; Skidmore, M.L.; et al. A Microbial Ecosystem beneath the West Antarctic Ice Sheet. Nature 2014, 512, 310-313. [CrossRef]

100. Zhang, G.; Zhang, W.; Liu, G.; An, L.; Chen, T.; Li, Z. Distribution of Aerobic Heterotrophic Bacteria Managed by Environmental Factors in Glacier Foreland. J. Glaciol. Geocryol. 2012, 34, 965-971.

101. Rime, T.; Hartmann, M.; Frey, B. Potential Sources of Microbial Colonizers in an Initial Soil Ecosystem after Retreat of an Alpine Glacier. ISME J. 2016, 10, 1625-1641. [CrossRef]

102. Yue, J.; Liu, G.; Zhang, G.; Zhang, W.; Xu, S. Changes in Soil Properties and Culturable Bacteria Diversity in Zhadang Glacier Foreland. J. Glaciol. Geocryol. 2010, 32, 1180-1185.

103. Liu, G.; Hu, P.; Zhang, W.; Wu, X. Variations in Soil Culturable Bacteria Communities and Biochemical Characteristics in the Dongkemadi Glacier Forefield along a Chronosequence. Folia Microbiol. (Praha) 2012, 57, 485-494. [CrossRef]

104. Wu, X.; Zhang, W.; Liu, G.; Yang, X.; Hu, P.; Chen, T.; Zhang, G.; Li, Z. Bacterial Diversity in the Foreland of the Tianshan No. 1 Glacier, China. Environ. Res. Lett. 2012, 7, 014038. [CrossRef]

105. Wang, Y.; Ma, A.; Zhong, G.; Xie, F.; Zhou, H.; Liu, G.; Zhuang, G. Effect of Simulated Warming on Microbial Community in Glacier Forefield. Environ. Sci. 2020, 41, 2918-2923. [CrossRef]

106. Wu, X.; Mao, W.; Tai, X.; Zhang, W.; Liu, G.; Chen, T.; Long, H.; Zhang, B.; Chen, N. Progress in Studies of Microbial Ecology in Glacier Foreland. J. Glaciol. Geocryol. 2013, 35, 217-223. [CrossRef]

107. Tian, J.; Qiao, Y.; Wu, B.; Chen, H.; Li, W.; Jiang, N.; Zhang, X.; Liu, X. Ecological Succession Pattern of Fungal Community in Soil along a Retreating Glacier. Front. Microbiol. 2017, 8, 1028. [CrossRef]

108. Hassan, N.; Rafiq, M.; Hayat, M.; Aamer, A.; Fariha, H. Psychrophilic and Psychrotrophic Fungi: A Comprehensive Review. Rev. Environ. Sci. Biotechnol. 2016, 15, 147-172. [CrossRef]

109. Wang, M.; Jiang, X.; Wu, W.; Hao, Y.; Cai, L.; Xiang, M.; Liu, X. Psychrophilic Fungi from the World's Roof. Persoonia Mol. Phylogeny Evol. Fungi 2015, 34, 100-102. [CrossRef]

110. Wang, X.; Gu, Y.; Ni, X.; Guan, B.; Ni, Y. Composition and Phylogeny of Fungal Community in Supraglacial Cryoconite and Subglacial Sediments of the Glacier No.1 at Headwaters of the Urumqi River in Tianshan Mountains. J. Glaciol. Geocryol. 2017, 39, 781-791. [CrossRef]

111. Zang, L.; Liu, Y.; Liu, X. Advance in Researches of Virus in Cryoconite on Glacier Surface. J. Glaciol. Geocryol. 2019, 41, 1-9.

112. Chen, T.; Zhang, W.; Liu, G.; Li, S. Microbes in Cryosphere: Opportunities and Challenges. Bull. Chin. Acad. Sci. 2020, 35, 434-442. [CrossRef]

113. Zhong, Z.-P.; Solonenko, N.E.; Li, Y.-F.; Gazitúa, M.C.; Roux, S.; Davis, M.E.; Van Etten, J.L.; Mosley-Thompson, E.; Rich, V.I.; Sullivan, M.B.; et al. Glacier Ice Archives Fifteen-Thousand-Year-Old Viruses. bioRxiv 2020. [CrossRef]

114. Anesio, A.; Mindl, B.; Laybourn-Parry, J.; Hodson, A.; Sattler, B. Viral Dynamics in Cryoconite Holes on a High Arctic Glacier (Svalbard). J. Geophys. Res. Biogeosci. 2007, 112, G04S31. [CrossRef]

115. Irvine-Fynn, T.D.L.; Edwards, A. A Frozen Asset: The Potential of Flow Cytometry in Constraining the Glacial Biome. Cytom. Part A J. Int. Soc. Anal. Cytol. 2014, 85, 3-7. [CrossRef]

116. Hood, E.; Battin, T.J.; Fellman, J.; O'neel, S.; Spencer, R.G.M. Storage and Release of Organic Carbon from Glaciers and Ice Sheets. Nat. Geosci. 2015, 8, 91-96. [CrossRef]

117. Wang, Y.; Ma, A.; Liu, G.; Ma, J.; Wei, J.; Zhou, H.; Brandt, K.K.; Zhuang, G. Potential Feedback Mediated by Soil Microbiome Response to Warming in a Glacier Forefield. Glob. Chang. Biol. 2020, 26, 697-708. [CrossRef] 
118. Treat, C.C.; Natali, S.M.; Ernakovich, J.; Iversen, C.M.; Lupascu, M.; Mcguire, A.D.; Norby, R.J.; Roy Chowdhury, T.; Richter, A.; Šantrůčková, H.; et al. A Pan-Arctic Synthesis of CH4 and CO2 Production from Anoxic Soil Incubations. Glob. Chang. Biol. 2015, 21, 2787-2803. [CrossRef]

119. Chen, Y.; Zhang, Z.; Liu, Y. Research Progress of Carbon Fixation Microorganisms in Glaciers. Acta Microbiol. Sin. 2020, 60, 2012-2029. [CrossRef]

120. Bradley, J.A.; Singarayer, J.S.; Anesio, A.M. Microbial Community Dynamics in the Forefield of Glaciers. Proc. R. Soc. B Biol. Sci. 2014, 281, 20140882. [CrossRef]

121. Wietrzyk-Pełka, P.; Rola, K.; Szymański, W.; Węgrzyn, M.H. Organic Carbon Accumulation in the Glacier Forelands with Regard to Variability of Environmental Conditions in Different Ecogenesis Stages of High Arctic Ecosystems. Sci. Total Environ. 2020, 717, 135151. [CrossRef]

122. Schulz, S.; Brankatschk, R.; Dümig, A.; Kögel-Knabner, I.; Schloter, M.; Zeyer, J. The Role of Microorganisms at Different Stages of Ecosystem Development for Soil Formation. Biogeosciences 2013, 10, 3983-3996. [CrossRef]

123. Li, W.; Yang, G.; Hu, J.; Zhu, Q.; Chen, H.; Peng, C.; Zhu, D.; Gao, Y. Soil Microbial Biomass Carbon and Nitrogen along the Glacial Retreat Sites of the Hailuogou Glacier. Chin. J. Appl. Environ. Biol. 2015, 21, 512-516. [CrossRef]

124. Lei, Y.; Zhou, J.; Xiao, H.; Duan, B.; Wu, Y.; Korpelainen, H.; Li, C. Soil Nematode Assemblages as Bioindicators of Primary Succession along a 120-Year-Old Chronosequence on the Hailuogou Glacier Forefield, SW China. Soil Biol. Biochem. 2015, 88, 362-371. [CrossRef]

125. Liu, G.; Li, S.; We, X.; Zhang, B.; Zhang, B.; Long, H.; Tai, X.; Li, Z. Studies on Rule and Mechanism of the Succession of Plant Community in the Retreat Forefield of the Tianshan Mountain Glacier No.1 at the Headwater of Urumqi River. J. Glaciol. Geocryol. 2012, 34, 1134-1141.

126. Bardgett, R.D.; Richter, A.; Bol, R.; Garnett, M.H.; Bäumler, R.; Xu, X.; Lopez-capel, E.; Manning, D.A.C.; Hobbs, P.J.; Hartley, I.R.; et al. Heterotrophic Microbial Communities Use Ancient Carbon Following Glacial Retreat Heterotrophic Microbial Communities Use Ancient Carbon Following Glacial Retreat. Biol. Lett. 2007, 3, 487-490. [CrossRef] [PubMed]

127. Wu, X.; Zhang, G.; Zhang, W.; Liu, G.; Chen, T. Variations in Culturable Bacterial Communities and Biochemical Properties in the Foreland of the Retreating Tianshan No. 1 Glacier. Braz. J. Microbiol. 2018, 49, 443-451. [CrossRef] [PubMed]

128. Zumsteg, A.; Bernasconi, S.M.; Zeyer, J.; Frey, B. Microbial Community and Activity Shifts after Soil Transplantation in a Glacier Forefield. Appl. Geochem. 2011, 26, S326-S329. [CrossRef]

129. Hahn, A.S.; Quideau, S.A. Shifts in Soil Microbial Community Biomass and Resource Utilization along a Canadian Glacier Chronosequence. Can. J. Soil Sci. 2013, 93, 305-318. [CrossRef]

130. Zheng, B.; Zhu, Y.; Sardans, J.; Peñuelas, J.; Su, J. QMEC:A Tool for High-Throughput Quantitative Assessment of Microbial Functional Potential in C, N, P and S Biogeochemical Cycling. Sci. China Life Sci. 2018, 61, 1451-1462. [CrossRef]

131. Esperschütz, J.; Pérez-De-Mora, A.; Schreiner, K.; Welzl, G.; Buegger, F.; Zeyer, J.; Hagedorn, F.; Munch, J.C.; Schloter, M. Microbial Food Web Dynamics along a Soil Chronosequence of a Glacier Forefield. Biogeosciences 2011, 8, 3283-3294. [CrossRef]

132. Sigler, W.V.; Zeyer, J. Microbial Diversity and Activity along the Forefields of Two Receding Glaciers. Microb Ecol. 2002, 43, 397-407. [CrossRef]

133. Sanyal, A.; Antony, R.; Samui, G.; Thamban, M. Microbial Communities and Their Potential for Degradation of Dissolved Organic Carbon in Cryoconite Hole Environments of Himalaya and Antarctica. Microbiol. Res. 2018, 208, 32-42. [CrossRef] [PubMed]

134. Price, G.D. Inorganic Carbon Transporters of the Cyanobacterial $\mathrm{CO}_{2}$ Concentrating Mechanism. Photosynth. Res. 2011, 109, 47-57. [CrossRef] [PubMed]

135. Cavicchioli, R. Microbial Ecology of Antarctic Aquatic Systems. Nat. Rev. Microbiol. 2015, 13, 691-706. [CrossRef] [PubMed]

136. Menendez, C.; Bauer, Z.; Huber, H.; GAD'On, N.; Stetter, K.-O.; Fuchs, G. Presence of Acetyl Coenzyme A (CoA) Carboxylase and Propionyl-CoA Carboxylase in Autotrophic Crenarchaeota and Indication for Operation of a 3-Hydroxypropionate Cycle in Autotrophic Carbon Fixation. J. Bacteriol. 1999, 181, 1088-1098. [CrossRef] [PubMed]

137. Evans, M.C.W.; Buchanan, B.B.; Arnon, D.I. A New Ferredoxin-Dependent Carbon Reduction Cycle in a Photosynthetic Bacterium. Proc. Natl. Acad. Sci. USA 1966, 55, 928-934. [CrossRef]

138. Li, Y.; Cha, Q.; Dang, Y.; Chen, X.; Wang, M.; Mcminn, A.; Espina, G.; Zhang, Y.; Blamey, J.M.; Qin, Q. Reconstruction of the Functional Ecosystem in the High Light, Low Temperature Union Glacier Region, Antarctica. Front. Microbiol. 2019, 10, 2408. [CrossRef]

139. Angeles Lezcano, M.; Moreno-Paz, M.; Carrizo, D.; Prieto-Ballesteros, O.; Angel Fernandez-Martinez, M.; Sanchez-Garcia, L.; Blanco, Y.; Puente-Sanchez, F.; de Diego-Castilla, G.; Garcia-Villadangos, M.; et al. Biomarker Profiling of Microbial Mats in the Geothermal Band of Cerro Caliente, Deception Island (Antarctica): Life at the Edge of Heat and Cold. Astrobiology 2019, 19, 1490-1504. [CrossRef]

140. Kong, W.; Liu, J.; Ji, M.; Yue, L.; Kang, S.; Morgan-kiss, R.M. Autotrophic Microbial Community Succession from Glacier Terminus to Downstream Waters on the Tibetan Plateau. FEMS Microbiol. Ecol. 2019, 95, fiz074. [CrossRef]

141. Kumar, V.; Thakur, V.; Ambika; Kumar, V.; Kumar, R.; Singh, D. Genomic Insights Revealed Physiological Diversity and Industrial Potential for Glaciimonas Sp. PCH181 Isolated from Satrundi Glacier in Pangi-Chamba Himalaya. Genomics 2020, 112, 637-646. [CrossRef]

142. Cameron, K.; Hodson, A.; Osborn, A. Carbon and Nitrogen Biogeochemical Cycling Potentials of Supraglacial Cryoconite Communities. Polar Biol. 2012, 35, 1375-1393. [CrossRef] 
143. Franzetti, A.; Tagliaferri, I.; Gandolfi, I.; Bestetti, G.; Minora, U.; Mayer, C.; Azzoni, R.S.; Diolaiuti, G.; Smiraglia, C.; Ambrosini, R. Light-Dependent Microbial Metabolisms Drive Carbon Fluxes on Glacier Surfaces. ISME J. 2016, 10, 2984-2988. [CrossRef] [PubMed]

144. Boyd, E.S.; Hamilton, T.L.; Havig, J.R.; Mark, L.; Shock, E.L.; Boyd, E.S.; Hamilton, T.L.; Havig, J.R.; Skidmore, M.L.; Shock, L. Chemolithotrophic Primary Production in a Subglacial Ecosystem. Appl. Environ. Microbiol. 2014, 80, 6146. [CrossRef] [PubMed]

145. Guelland, K.; Hagedorn, F.; Smittenberg, R.H.; Göransson, H.; Bernasconi, S.M.; Hajdas, I.; Kretzschmar, R. Evolution of Carbon Fluxes during Initial Soil Formation along the Forefield of Damma Glacier, Switzerland. Biogeochemistry 2013, 113, 545-561. [CrossRef]

146. Rime, T.; Hartmann, M.; Stierli, B.; Anesio, A.M.; Frey, B. Assimilation of Microbial and Plant Carbon by Active Prokaryotic and Fungal Populations in Glacial Forefields. Soil Biol. Biochem. 2016, 98, 30-41. [CrossRef]

147. Guelland, K.; Esperschütz, J.; Bornhauser, D.; Bernasconi, S.M.; Kretzschmar, R.; Hagedorn, F. Mineralisation and Leaching of C from 13C Labelled Plant Litter along an Initial Soil Chronosequence of a Glacier Forefield. Soil Biol. Biochem. 2013, 57, $237-247$. [CrossRef]

148. Bardgett, R.D.; Freeman, C.; Ostle, N.J. Microbial Contributions to Climate Change through Carbon Cycle Feedbacks. ISME J. 2008, 2, 805-814. [CrossRef]

149. Crowther, T.W.; Todd-Brown, K.E.O.; Rowe, C.W.; Wieder, W.R.; Carey, J.C.; MacHmuller, M.B.; Snoek, B.L.; Fang, S.; Zhou, G.; Allison, S.D.; et al. Quantifying Global Soil Carbon Losses in Response to Warming. Nature 2016, 540, 104-108. [CrossRef]

150. Treat, C.C.; Wollheim, W.M.; Varner, R.K.; Grandy, A.S.; Talbot, J.; Frolking, S. Temperature and Peat Type Control CO2 and CH4 Production in Alaskan Permafrost Peats. Glob. Chang. Biol. 2014, 20, 2674-2686. [CrossRef]

151. Hagedorn, F.; Martin, M.; Rixen, C.; Rusch, S.; Bebi, P.; Zürcher, A.; Siegwolf, R.T.W.; Wipf, S.; Escape, C.; Roy, J.; et al. Short-Term Responses of Ecosystem Carbon Fluxes to Experimental Soil Warming at the Swiss Alpine Treeline. Biogeochemistry 2010, 97, 7-19. [CrossRef]

152. Melillo, J.M.; Steudler, P.A.; Aber, J.D.; Newkirk, K.; Lux, H.; Bowles, F.P.; Catricala, C.; Magill, A.; Ahrens, T.; Morrisseau, S. Soil Warming and Carbon-Cycle Feedbacks to the Climate System. Science 2002, 298, 2173-2176. [CrossRef] [PubMed]

153. Knoblauch, C.; Beer, C.; Sosnin, A.; Wagner, D.; Pfeiffer, E.M. Predicting Long-Term Carbon Mineralization and Trace Gas Production from Thawing Permafrost of Northeast Siberia. Glob. Chang. Biol. 2013, 19, 1160-1172. [CrossRef] [PubMed]

154. Li, J.; Wang, G.; Mayes, M.A.; Allison, S.D.; Frey, S.D.; Shi, Z.; Hu, X.M.; Luo, Y.; Melillo, J.M. Reduced Carbon Use Efficiency and Increased Microbial Turnover with Soil Warming. Glob. Chang. Biol. 2019, 25, 900-910. [CrossRef] [PubMed]

155. Monteux, S.; Weedon, J.T.; Blume-Werry, G.; Gavazov, K.; Jassey, V.E.J.; Johansson, M.; Keuper, F.; Olid, C.; Dorrepaal, E. Long-Term in Situ Permafrost Thaw Effects on Bacterial Communities and Potential Aerobic Respiration. ISME J. 2018, 12, 2129-2141. [CrossRef] [PubMed]

156. MacKelprang, R.; Waldrop, M.P.; Deangelis, K.M.; David, M.M.; Chavarria, K.L.; Blazewicz, S.J.; Rubin, E.M.; Jansson, J.K. Metagenomic Analysis of a Permafrost Microbial Community Reveals a Rapid Response to Thaw. Nature 2011, 480, 368-371. [CrossRef] [PubMed]

157. Margesin, R.; Miteva, V. Diversity and Ecology of Psychrophilic Microorganisms. Res. Microbiol. 2011, 162, 346-361. [CrossRef]

158. Jiang, Y.; Lei, Y.; Qin, W.; Korpelainen, H.; Li, C. Revealing Microbial Processes and Nutrient Limitation in Soil through Ecoenzymatic Stoichiometry and Glomalin-Related Soil Proteins in a Retreating Glacier Fore Fi Eld. Geoderma 2019, 338, 313-324. [CrossRef]

159. Jiang, Y.; Jiang, J. Screening and Phylogenetic Analysis of Lipase-Producing Yeast from Tianshan No.1 Glacier. Light Ind. Sci. Technol. 2016, 32, 1-3, 6 .

160. Wu, Y.; Kumula; Zhang, X.; Wang, W.; Gulinazi; Wanglu; Chen, W.; Miaosen; Gao, W. Molecular Biologic Identification of Some Bacteria Strains Producing Low Temperature Amylase Isolated and Enzymatic Characterization from Frozen Soil in Xinjiang Glacier Ice Margin. Xinjiang Agric. Sci. 2013, 50, 1288-1296.

161. Ni, Y.; Gu, Y.; Shi, X.; Zheng, X.; Han, L.; Zhou, H.; Cheng, G. Phylogenetic and Physiological Diversity of Cold-Adapted Bacteria Producing Protease from Sediiments of the Bottom Layer of the Glacier No. 1 in the Tianshan Mountains. Acta Microbiol. Sin. 2013, 53, 164-172. [CrossRef] 